\title{
Residue Oil Desulfurization Using Oxidation and Extraction Method
}

\author{
Rizky Tetrisyanda, Annas Wiguno, Rizqy Romadhona Ginting, \\ M. Chadiq Dzikrillah, and Gede Wibawa*
}

Department of Chemical Engineering, Institut Teknologi Sepuluh Nopember (ITS), Kampus ITS Sukolilo, Surabaya 60111 Indonesia

Received July 18, 2017; Accepted September 11, 2017

\begin{abstract}
This study successfully improved the performance of oxidative desulfurization method to reduce sulfur content from residue oil (condensate) with modifications of oxidation and extraction steps epeated for several stages. Residue oil used in this study contained $386.2 \mathrm{ppm}$ of initial sulfur content. In oxidation process, $\mathrm{H}_{2} \mathrm{O}_{2}$ as oxidizer and acid as catalyst were used within temperature range of $30-60{ }^{\circ} \mathrm{C}$ and for interval time from 30 to $120 \mathrm{~min}$. In extraction process, various alcohol solvents (methanol, ethanol, and propanol) were used at the temperature of 30 ${ }^{\circ} \mathrm{C}$ for 30 min toward every ratio of residue oil to solvent $(\mathrm{v} / \mathrm{v})$. The best reducing sulfur result was $35.9 \mathrm{ppm}$ or $90.7 \%$ desulfurization, and it was achieved after 4 recursively extractions using ethanol as the solvent. This study successfully reduced sulfur content in residue oil to meet the international standard (<50 ppm).
\end{abstract}

Keywords: extraction; oxidation; oxidative desulfurization; residue oil

\section{ABSTRAK}

Studi ini telah berhasil meningkatkan performa dari metode desulfurisasi oksidatif untuk menurunkan kadar sulfur pada minyak residu (kondensat) dengan modifikasi pada proses oksidasi dan ekstraksi yang dilakukan beberapa tahap. Minyak residu yang digunakan pada studi ini mengandung sulfur dengan konsentrasi awal sebesar 386,6 ppm. Pada proses oksidasi, $\mathrm{H}_{2} \mathrm{O}_{2}$ sebagai pengoksidasi dan katalis asam digunakan pada rentang suhu dari 30-60 ${ }^{\circ} \mathrm{C}$ dan rentang waktu dari 30 sampai 120 menit. Pada proses ekstraksi, berbagai macam alkohol (metanol, etanol dan propanol) digunakan sebagai pelarut pada suhu $30{ }^{\circ} \mathrm{C}$ dan waktu 30 menit untuk setiap rasio minyak residu terhadap solvent ( $\mathrm{V} / \mathrm{v}$ ). Hasil terbaik pada penurunan kadar sulfur yang didapatkan adalah sebesar 35,9 ppm atau 90,7\% desulfurisasi. Hasil tersebut dicapai setelah melakukan 4 tahapan ekstraksi secara berulang dengan menggunakan etanol sebagai pelarut. Studi ini telah berhasil mencapai target untuk menurunkan kadar sulfur dalam minyak residu untuk memenuhi standar internasional (<50 ppm).

Kata Kunci: ekstraksi; oksidasi; desulfurisasi oksidatif; minyak residu

\section{INTRODUCTION}

In general, natural gas is hydrocarbon gas mixture which mostly consist of light component $\left(\mathrm{C}_{1}-\mathrm{C}_{4}\right)$, heavy component $\left(\mathrm{C}_{5}{ }^{+}\right)$and small amount of carbon dioxide, nitrogen, hydrogen sulfide, or helium. Natural gas is one of Indonesia's natural resources that can be processed into various products of energy such as liquefied natural gas (LNG). Residue oil (condensate) is byproduct which obtained from LNG production. The residue oil has quality similar to crude oil. In the daily life, residue oil is widely used as a solvent in industrial processing, raw material in petrochemical industry and fuel for vehicles. Because of its advantages, residue oil is an important commodity in Indonesia.

The major component of residue oil is Addi. In addition to major component, residue oil contains contaminant such as carbon dioxide and sulfur. Because

* Corresponding author.

Email address : gwibawa@chem-eng.its.ac.id sulfur is an acid gas, it can harm the environment and convert to $\mathrm{SO}_{x}$ compound in combustion process. $\mathrm{SO}_{x}$ is the main source of acid rain and air pollution [1-3]. High sulfur content is not only affecting the environment, but also cause adverse effects on the quality petroleum and natural gas products as it may reduce API gravity, decrease octane rating and release toxic hydrogen sulfide [4-5].

Sulfur removal in liquid fuels such as kerosene, gasoline, diesel fuel, and residue oil is relatively more difficult than that in natural gas, therefore the proper method of removing sulfur content in liquid fuels is important. Conventional method to remove sulfur usually involving hydrogen gas at high operating condition and using expensive catalyst [6-7]. The process of sulfur removal in liquid fuels is generally done by Hydrodesulfurization (HDS) process. Hydrodesulfurization is a standard catalytic process for 
removing sulfur from petroleum products that have been developed since 1930. In this process, the crude oil is heated and then mixed with hydrogen and catalyst to convert sulfur content into hydrogen sulfide. To meet the standard sulfur content of less than $50 \mathrm{ppm}$, the hydrodesulfurization method should be operate at high temperature $\left(300-400{ }^{\circ} \mathrm{C}\right)$ and pressure (30-130 atm) and require highly active catalysts. The capital and operating cost is high to be operate in the industry [8]. Therefore, various desulfurization techniques have been developed for the removal of sulfur in liquid fuels including microwaves, bacteria, electricity, adsorption, and extraction $[3,9]$. The most prospective technique in terms of both economic and technical process is Oxidative Desulfurization [10].

The oxidative desulfurization (ODS) is a promising and alternative method for sulfur removal because it has several advantages over the hydrodesulfurization method. The advantage of the this method is the sulfur removal reaction takes place at low temperature and pressure so that it does not require high energy, has high selectivity, and low investment cost. This method also does not require expensive materials such as hydrogen. Hence oxidative desulfurization method could provide sulfur removal solutions on liquid fuels effectively in technical process and economy aspect [11]. The ODS method was applied during kerosene desulfurization using $\mathrm{H}_{2} \mathrm{O}_{2}-\mathrm{CH}_{3} \mathrm{COOH}$ system with constant stirring for several hours [12-13]. The solvents used were acetonitrile, methanol, ethanol, and propanol has potential to be utilized in desulfurization. But recent study showed a new technology to take advantage of ionic liquids (ILs) as desulfurization agent [1-2,5,14-15]. It is because ILs has advantage in its properties, such as thermal stability and volatility, which can be designed with specific purposes [16]. The major drawback to utilize ILs is very high-cost materials.

In addition to hydrodesulfurization and oxidative desulfurization methods, the biodesulfurization (BDS) method can be used for sulfur removal in various fuel [3,17-18]. Biodesulfurization method is a biological sulfur removal process which the sulfur content in liquid fuel will be consumed by microorganisms. This method required microorganisms and its media breeding to maintain the viability of these microorganisms [19].

An alternative method of sulfur removal that has the best prospects in terms of process and economy is oxidative desulfurization. In this study, the performance of the oxidative desulfurization method using technical grade solvents were investigated and applied on residual oil samples. It is expected to eliminate sulfur content in the sample to meet liquid fuel standards $(<$ $50 \mathrm{ppm}$ ). This study also develope ingenious technology to be applied in industry.

\section{EXPERIMENTAL SECTION}

\section{Materials}

Residue oil used in this study contained 386.2 ppm of sulfur. The residue oil was obtained from Indonesia's oil and gas company. Hydrogen peroxide oxidizer was used with acetic acid and formic acid as catalysts in the oxidation stage. For the extraction stage, solvents methanol, ethanol, and propanol were used. The specifications of each material obtained from the supplier were shown in Table 1.

\section{Procedure}

Oxidative desulfurization is an oxidation process of residue oil with a hydrogen peroxide as oxidizer $\left(\mathrm{H}_{2} \mathrm{O}_{2}\right)$ using acid catalyst to form an easily extractable compound by increasing the relative polarity. Oxidant compounds provide oxygen atoms bonding sulfur in thiols, sulfides, disulfides, and thiophene to form sulfoxides and sulfones then followed by liquid-liquid extraction to remove further sulfur content. The procedure used in this study consisted of two steps, namely the oxidation step and extraction step. The modification done in this research was performed multiple stage of extraction. The block diagram of oxidative desulfurization method in this experiment was shown in Fig.1.

Table 1. Specification of material used in the experiment

\begin{tabular}{clccccc}
\hline No & \multicolumn{1}{c}{ Material } & Grade & $\begin{array}{c}\text { Molecular Weight } \\
(\mathrm{g} / \mathrm{mol})\end{array}$ & $\begin{array}{c}\text { Density } \\
\left(\mathrm{g} / \mathrm{cm}^{3}\right) 3\end{array}$ & $\begin{array}{c}\text { Normal Boiling Point } \\
\left({ }^{\circ} \mathrm{C}\right)\end{array}$ & $\begin{array}{c}\text { Polarity } \\
\text { Index }\end{array}$ \\
\hline 1. & Hydrogen/Peroxide & $35 \%$ & 34.01 & 1.4463 & 150.2 & - \\
2. & Acetic Acid & p.a & 60.05 & 1.0490 & 118.1 & - \\
3. & Formic Acid & p.a & 46.03 & 1.2200 & 100.8 & - \\
4. & Methanol & $50 \%$ & 32.13 & 0.7918 & 64.7 & 5.1 \\
5. & Ethanol & $50 \%$ & 46.07 & 0.7890 & 78.4 & 5.2 \\
6. & Propanol & $50 \%$ & 60.10 & 0.8034 & 97.1 & 4 \\
\hline
\end{tabular}




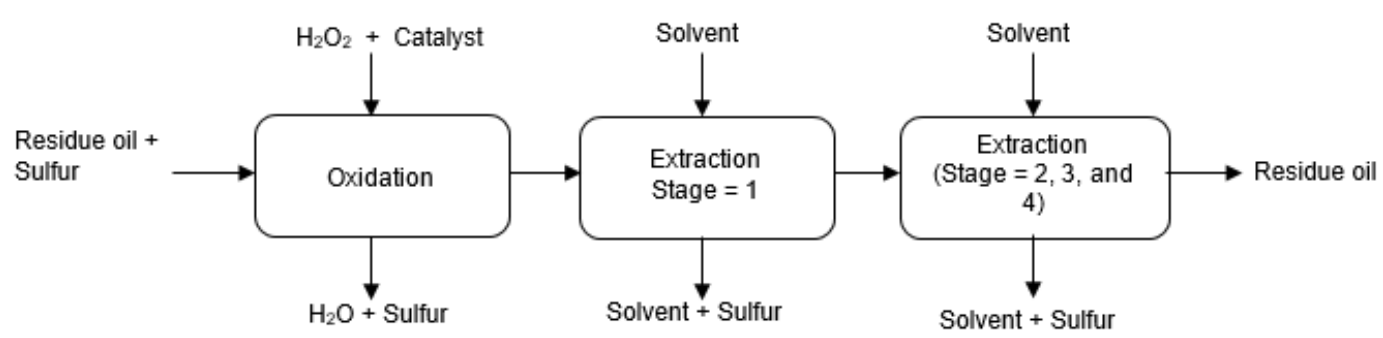

Fig 1. Oxidative desulfurization block diagram

\section{Oxidation step}

The oxidation step was carried out by mixing 100 $\mathrm{mL}$ of oil residue and catalysts (acetic acid or formic acid) with reside oil/catalyst $(\mathrm{v} / \mathrm{v})$ ratio of $10,15,25$, and 30 into a flatbed flask equipped with a thermometer. The mixture was heated over a hot plate equipped with a magnetic stirrer to various temperature variables $(40,50$, and $60{ }^{\circ} \mathrm{C}$ ) with constant stirring. After constant temperature, hydrogen peroxide was added with the ratio of residue oil/ $/ \mathrm{H}_{2} \mathrm{O}_{2}(\mathrm{v} / \mathrm{v})$ of $10,25,40$, and 50 to the mixture. The reaction time was set for $120 \mathrm{~min}$, and after that the stirring was stopped. During the oxidation step, $5 \mathrm{~mL}$ of sample was taken for every $30 \mathrm{~min}$; then it was analyzed using XRF (X-Ray Fluorescence) method. The two phases formed from the oxidation results were completely separated between the aqueous and the residual oil phases in the separating funnel. The residue oil phase was analyzed using XRF method to measure sulfur content of the oxidized residue oil. The oxidation experimental process was repeated 4 times to obtain precise data.

\section{Extraction step}

The residue oil obtained from oxidation step subsequently then to be continued with the liquid-liquid extraction step by mixing the oxidized residue oil with solvent (methanol, ethanol, and propanol) into the flatbed flask with the residue oil/solvent ratio $(\mathrm{v} / \mathrm{v})$ of 0.5 , 1,2 , and 4 . The mixture was heated to temperature of $30^{\circ} \mathrm{C}$ accompanied by constant stirring for $30 \mathrm{~min}$. Then the raffinate and extract phase was separated using separation funnel for $30 \mathrm{~min}$. The sample was taken from both solvents to be analyzed the sulfur content by XRF method. In this study, the effect of extraction stage on the percentage of desulfurization was studied; therefore the residual oil was extracted 4 times with the similar procedure.

\section{RESULT AND DISCUSSION}

In this study, variation in the ratio of residue oil $/ \mathrm{H}_{2} \mathrm{O}_{2}$ and residue oil/catalyst $(\mathrm{v} / \mathrm{v})$, variation in oxidation temperature and variation of oxidation time was conducted to determine parameters in the desulfurization oxidation method. In addition, to better

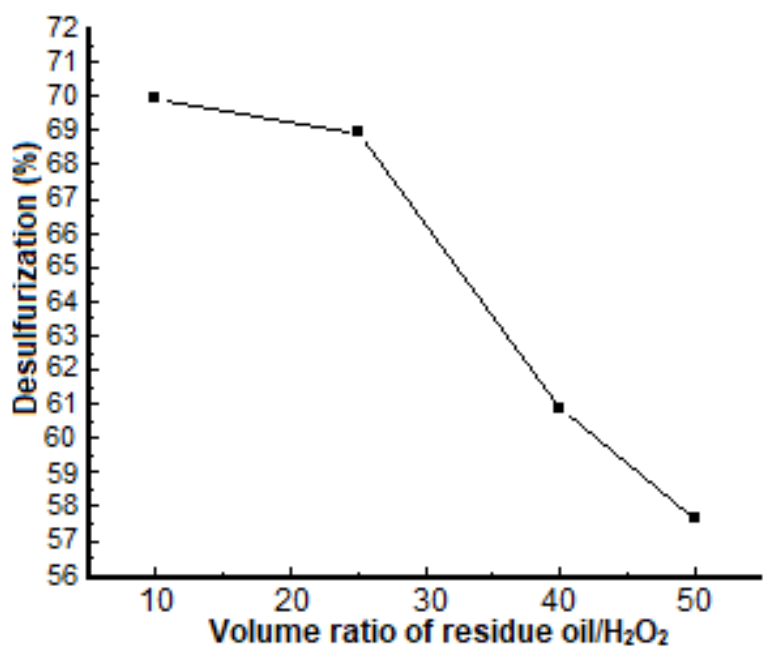

Fig 2. The effect of volume ratio residue oil/ $/ \mathrm{H}_{2} \mathrm{O}_{2}$ ratio to percent desulfurization with operating condition residue oil volume $100 \mathrm{~mL}$, ratio of residue oil/acetic acid $10(\mathrm{v} / \mathrm{v})$, oxidation temperature $50{ }^{\circ} \mathrm{C}$, oxidation time $120 \mathrm{~min}$, ratio of residue oil/ $/ \mathrm{H}_{2} \mathrm{O}_{2} 10 ; 25 ; 40 ; 50$ $(\mathrm{v} / \mathrm{v})]$

understand the performance of solvent in the extraction stage, this study conducted variations of the ratio of residual oil/solvent $(\mathrm{v} / \mathrm{v})$ and number of extraction stage.

\section{Effect of Oxidizing Agent and Catalyst}

During the oxidation step of this experiment, the sulfur compound would be converted to sulfone and sulfoxide. From Fig. 2, it was shown the percentage of desulfurization on various residue oil/ $\mathrm{H}_{2} \mathrm{O}_{2}$ ratio. At 10 $(\mathrm{v} / \mathrm{v})$, the sulfur removal was $69.93 \%$. However, it was less efficient to compare to $25(\mathrm{v} / \mathrm{v})$ residue oil/ $\mathrm{H}_{2} \mathrm{O}_{2}$ ratio, which resulting $68.92 \%$ desulfurization. It could be explained that the increase of $\mathrm{H}_{2} \mathrm{O}_{2}$ oxidizer may increase the percentage of desulfurization. Hydrogen peroxide will donate oxygen radicals and react with acetic acid catalysts to form peracid radicals ( $R$ $\mathrm{CH}_{3} \mathrm{COO}$ ). This radical will be offset with sulfur substances in the residue of oil so it will be more polar. Furthermore, these compounds will form two layers of residue oil and oxidized sulfur compounds. The oxidation 


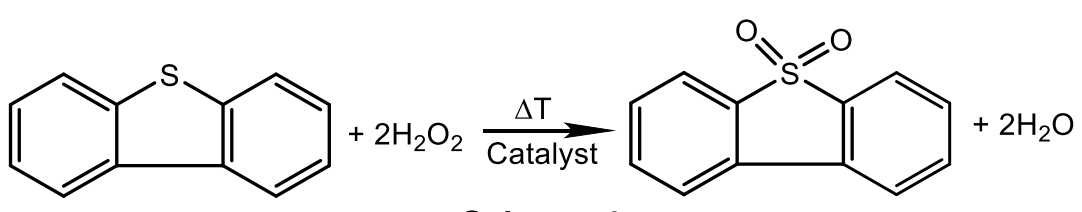

Scheme 1<smiles>CCCOO</smiles>

Scheme 2<smiles></smiles>

reaction takes place as Scheme 1. The byproduct of hydrogen peroxide decomposition is water, therefore, it more environmentally friendly.

Study conducted by Dehkordi et al., (2009) shown that the oxidation rate of $\mathrm{H}_{2} \mathrm{O}_{2}$ is strongly influenced by oxidation temperature when the oxidation temperature of $25^{\circ} \mathrm{C}$ [12]. The increase amount of $\mathrm{H}_{2} \mathrm{O}_{2}$ oxidizer were resulting decreasing of percent desulfurization while at $60{ }^{\circ} \mathrm{C}$ the addition of $\mathrm{H}_{2} \mathrm{O}_{2}$ were resulting increasing of percentage desulfurization. Similar results were obtained in this study, at a temperature of $50{ }^{\circ} \mathrm{C}$ the addition of oxidizing amounts led to an increase in percentage of desulfurization. Therefore, for subsequent research used the ratio of residual oil/ $\mathrm{H}_{2} \mathrm{O}_{2} 25(\mathrm{v} / \mathrm{v})$.

Acetic acid and formic acid are carboxylic acids that often use for the removal of sulfuric materials in liquid fuels such as gasoline, kerosene, and diesel oil. The effect of acetic acid and formic acid catalyst are observed by the ratio of residue oil/catalyst (v/v) used $(10,15,25$, and $30(\mathrm{v} / \mathrm{v})$ for each acetic acid and formic acid). The results is shown in Fig. 3 and $t$ is shown that the percentage of desulfurization is higher using acetic acid as catalyst than using formic acid. With residue oil/formic acid ratio is $10(\mathrm{v} / \mathrm{v})$, the desulfurization by using acetic acid is $71.9 \%$ whereas with formic acid $64.6 \%$ as shown in Fig. 3. In other words, the addition of $10(\mathrm{v} / \mathrm{v})$ ratio of residue oil/acetic acid reduce sulfur content from the initial value 386.2 to $108.7 \mathrm{ppm}$. If there is no addition of catalyst, it will require large number of oxidizers, long reaction time and the percent of desulfurization produced is not high, $13.7 \%$. Therefore, for further research, the composition of residue oil/acetic acid ratio $(\mathrm{v} / \mathrm{v})$ is 10 .

From Fig. 3, it can be explained that the addition of the catalyst (the ratio of the residue oil/catalyst decrease) increasing the percentage of desulfurization, the catalyst acts to accelerate the reaction by decreasing the activation energy. Acetic acid as the catalyst will react with hydrogen peroxide to form peracid radical ( $R$ $\mathrm{CH}_{3} \mathrm{COO}$ ). This compound is more reactive and has high oxidizing ability compared to performic radicals $\left(\mathrm{CH}_{2} \mathrm{O}_{3}\right)$ [20]. The reaction of performic radical formation takes place as Scheme 2.

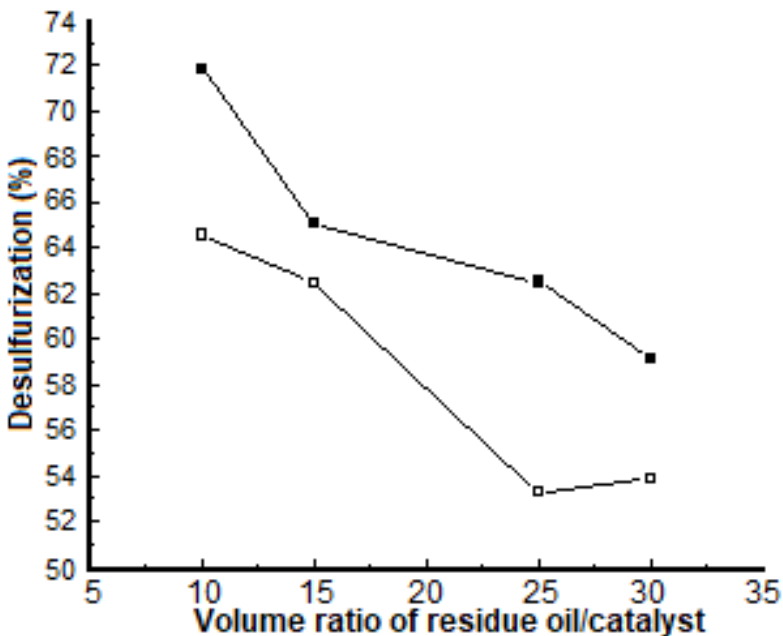

Fig 3. The effect of volume ratio residue oil/catalyst acetic acid (-m-) or formic acid (-口-) to percent desulfurization with operating condition residue oil volume $100 \mathrm{~mL}$, oxidation temperature $40^{\circ} \mathrm{C}$, oxidation time $120 \mathrm{~min}$, ratio of residue oil/ $\mathrm{H}_{2} \mathrm{O}_{2} 25(\mathrm{v} / \mathrm{v})$, ratio of residue oil/catalyst $10 ; 15 ; 25 ; 30$ (v/v)

However, performic radicals are more stable which is less reactive than peracid. Therefore, peracid radicals more easily oxidize the residual oil to sulfone and sulfoxide so that the percent of desulfurization of acetic acid is higher than formic acid [21].

\section{Effect of Oxidation Temperature}

Based on the analysis results shown in Fig. 4, it can be explained that the highest percentage of desulfurization at temperature $50{ }^{\circ} \mathrm{C}$ which is $77.6 \%$ desulfurization, so that the sulfur content decreases from 386.26 to $86.37 \mathrm{ppm}$.

The increasing of oxidation temperature causes an increase in percentage of desulfurization, where the temperature changes from 30,40 and $50{ }^{\circ} \mathrm{C}$ cause a significant 45, 73.5, and 77.6\% desulfurization, respectively. High temperatures accelerate the oxidation reaction by increasing the rate of oxidation reaction. However, at a temperature of $60^{\circ} \mathrm{C}$, there was 


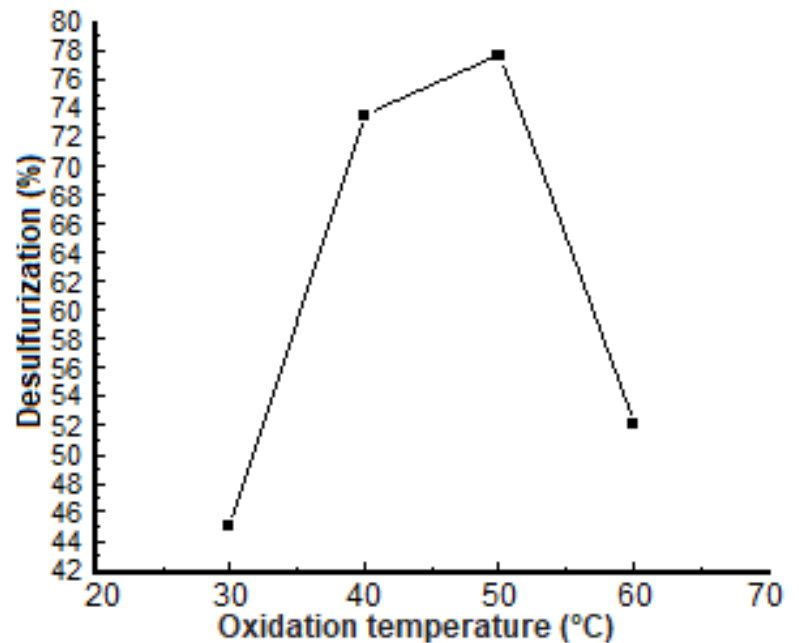

Fig 4. The effect of oxidation temperature to percent desulfurization with operating condition residue oil volume $100 \mathrm{~mL}$, oxidation time $120 \mathrm{~min}$, ratio of residue oil/ $\mathrm{H}_{2} \mathrm{O}_{2} 25(\mathrm{v} / \mathrm{v})$, ratio of residue oil/acetic acid $10(\mathrm{v} / \mathrm{v})$, oxidation temperature $30,40,50$ and $60^{\circ} \mathrm{C}$

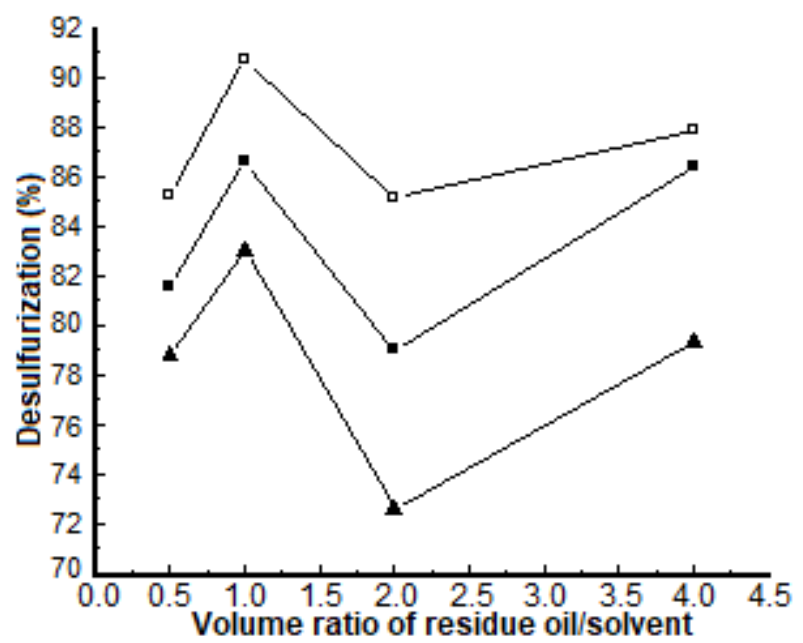

Fig 6. The effect of solvent methanol (-口-), ethanol (-口-) or propanol $(-\boldsymbol{\Delta}-)$ used in the extraction process to percent desulfurization with operating condition residue oil volume $100 \mathrm{~mL}$, oxidation time $120 \mathrm{~min}$, oxidation temperature $50{ }^{\circ} \mathrm{C}$, ratio of residue oil/ $\mathrm{H}_{2} \mathrm{O}_{2} 25(\mathrm{v} / \mathrm{v})$, ratio of residue oil/acetic acid $10(\mathrm{v} / \mathrm{v})$, extraction temperature $30{ }^{\circ} \mathrm{C}$, extraction time $30 \mathrm{~min}$, ratio of residue oil/solvent $0.5 ; 1 ; 2 ; 4(\mathrm{v} / \mathrm{v})$

a decline of desulfurization to $52.1 \%$ as shown in Fig. 4. This is because the oxidation temperature approaching to $80{ }^{\circ} \mathrm{C}$ where the $\mathrm{H}_{2} \mathrm{O}_{2}$ compound start to be degraded.

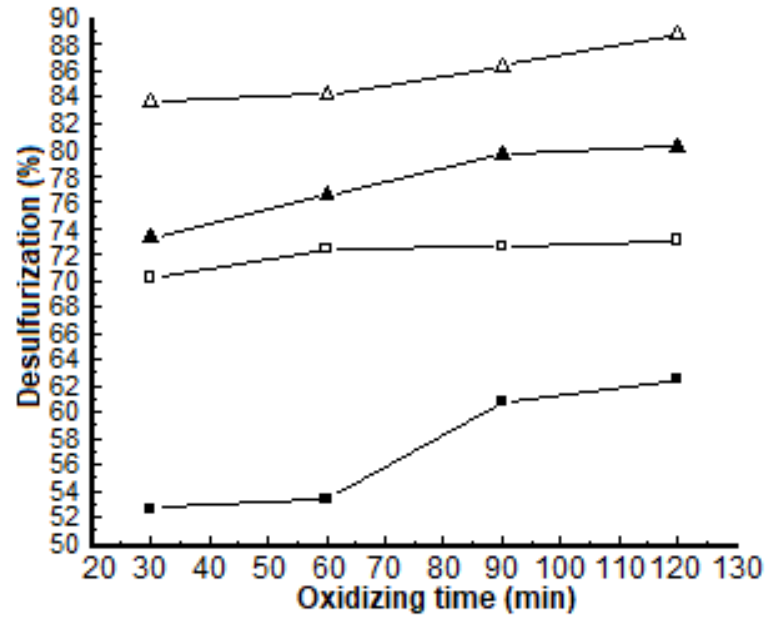

Fig 5. The effect of oxidation time to percent

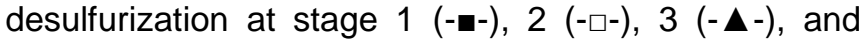
$4(-\Delta-)$ with operating condition residue oil volume $100 \mathrm{~mL}$, oxidation temperature $50^{\circ} \mathrm{C}$, ratio of residue oil/ $\mathrm{H}_{2} \mathrm{O}_{2} 25(\mathrm{v} / \mathrm{v})$, ratio of residue oil/acetic acid $10(\mathrm{v} / \mathrm{v})$, oxidation time $30 ; 60 ; 90 ; 120 \mathrm{~min}$

\section{Effect of Oxidation Time}

The time of oxidation gives a subtle difference in percentage of desulfurization. Based on Fig. 5, it could be explained that the percent of desulfurization increased start from 30 to $90 \mathrm{~min}$. After that, it is continuously constant until the $120 \mathrm{~min}$ for every oxidation stage. The highest percentage of desulfurization was obtained at the stage 4 and 120 min oxidation process, which was $88.9 \%$ desulfurization. Therefore, to increase percent desulfurization can be done with several methods such as applying oxidation stage. This is because the oxidation stage can increase the effectiveness of oxidation reactions (increased mass transfer). Although in this study oxidation process is done until the 4 stages but each stage takes $2 \mathrm{~h}$ hence the desulfurization process lasts longer. With economic considerations, oxidation stages are inefficient and difficult to apply in industry.

\section{Effect of Solvent Used in the Extraction Process}

Methanol, ethanol, and propanol are used in the extraction step as solvent because they are selective against sulfones, sulfoxides, and water that are polar in order to be separated by decantation. From the analysis results shown in Fig. 6, it can be explained that ethanol has the highest desulfurization among the 


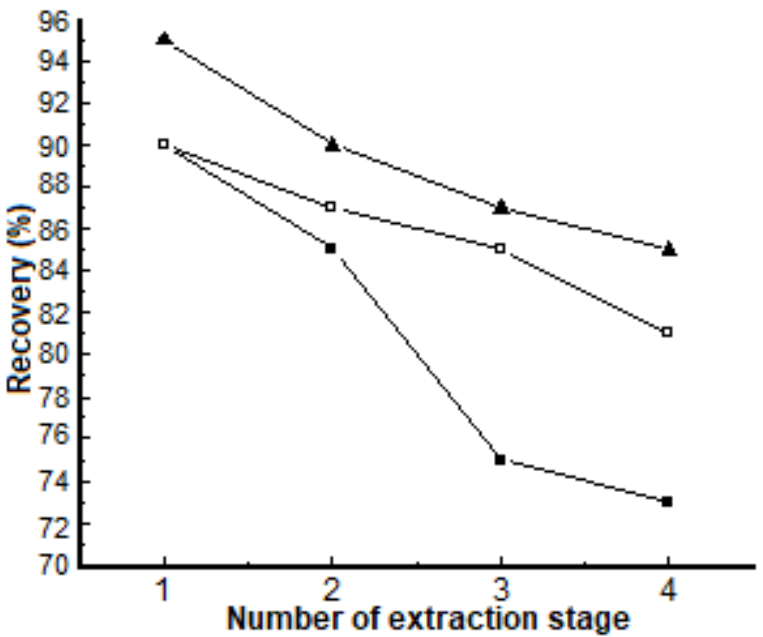

Fig 7. The effect of solvent methanol (-ם-), ethanol (-口-) or propanol $(-\mathbf{\Delta}-)$ used in the extraction process to percent solvent recovery [residue oil volume $100 \mathrm{~mL}$, oxidation time $120 \mathrm{~min}$, oxidation temperature $50{ }^{\circ} \mathrm{C}$, ratio of residue oil/ $/ \mathrm{H}_{2} \mathrm{O}_{2} 25(\mathrm{v} / \mathrm{v})$, ratio of residue oil/acetic acid $10(\mathrm{v} / \mathrm{v})$, extraction temperature $30{ }^{\circ} \mathrm{C}$, extraction time $30 \mathrm{~min}$, ratio of residue oil/solvent $1(\mathrm{v} / \mathrm{v})$ ]

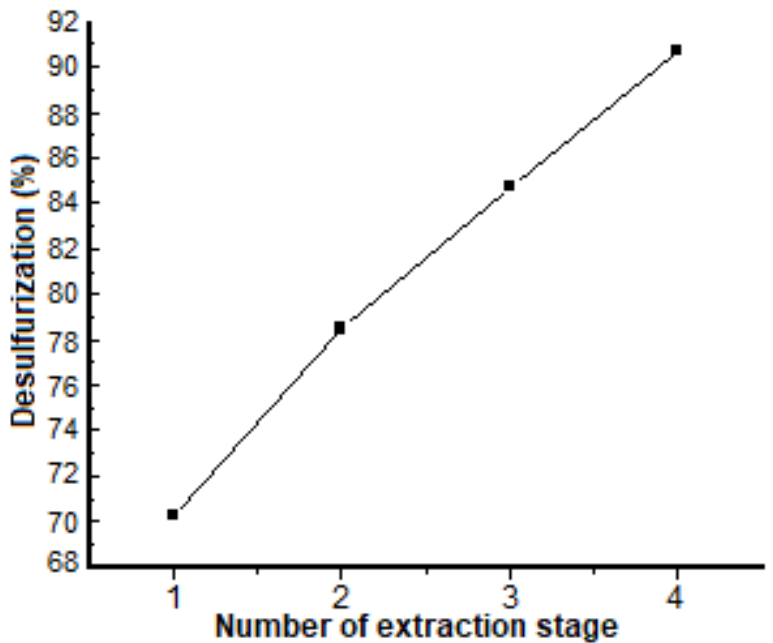

Fig 8. The effect of number of extraction stage to percent desulfurization [residue oil volume $100 \mathrm{~mL}$, oxidation time $120 \mathrm{~min}$, oxidation temperature $50^{\circ} \mathrm{C}$, ratio of residue oil/ $/ \mathrm{H}_{2} \mathrm{O}_{2} 25(\mathrm{v} / \mathrm{v})$, ratio of residue oil/acetic acid $10(\mathrm{v} / \mathrm{v})$, extraction temperature $30^{\circ} \mathrm{C}$, extraction time $30 \mathrm{~min}$, ratio of residue oil/ ethanol 1 $(\mathrm{v} / \mathrm{v})]$

Table 2. Solvent effectiveness

\begin{tabular}{cccc}
\hline Solvent & $\begin{array}{c}\text { Desulfurization* } \\
(\%)\end{array}$ & $\begin{array}{c}\text { Residue oil Recovery* } \\
(\%)\end{array}$ & $\begin{array}{c}\text { Solvent } \\
\text { Effectiveness }\end{array}$ \\
\hline Methanol & 86.6 & 73 & 5.6 \\
Ethanol & 90.7 & 81 & 9 \\
Propanol & 83.3 & 85 & 5 \\
\hline${ }^{*}$ residue oil volume $100 \mathrm{~mL}$, oxidation time $120 \mathrm{~min}$, oxidation temperature $50{ }^{\circ} \mathrm{C}$, \\
ratio of residue oil/ $\mathrm{H}_{2} \mathrm{O}_{2} 25(\mathrm{v} / \mathrm{v})$, ratio of residue oil/acetic acid $10(\mathrm{v} / \mathrm{v})$, extraction \\
temperature $30{ }^{\circ} \mathrm{C}$, extraction time $30 \mathrm{~min}$, ratio of residue oil/solvent $1(\mathrm{v} / \mathrm{v})$, \\
extraction stage 4]
\end{tabular}

solvent used in this study. At the ratio of residue oil/solvent $1(\mathrm{v} / \mathrm{v})$, the desulfurization using ethanol, methanol, and propanol are 90.7, 86.6 and $83.3 \%$, respectively. For every residue oil/solvent ratio, ethanol showed better percentage of desulfurization than methanol and propanol.

Based on the experiment results, the ability of ethanol to remove sulfur content in the residue oil is superior. This is because the polarity of the ethanol index of 5.2 is greater than that of methanol of 5.1 and propanol of 4 . The larger the polarity index, the greater the ability to extract the oxidized sulfur content. In addition, ethanol has better capability than methanol and propanol is also due to the density. A large difference in density between the solvent and residue oil make the separation process easier to separate. The density of methanol of $0.7818 \mathrm{~g} / \mathrm{cm}^{3}$ is similar to the residue oil of $0.7340 \mathrm{~g} / \mathrm{cm}^{3}$ hence it is difficult to separate.

In addition to desulfurization capability, the solvents used in extraction must have a high percent of residue oil recovery so that it is not reducing the amount of product. Based on Fig. 7, it could be explained that in the ratio of residual oil/solvent, solvent propanol has the highest recovery percentage of $85 \%$ when compared with ethanol and methanol at each extraction stage. Methanol has the lowest recovery percent because it has a density similar to the residual oil. Therefore, to determine the best solvent, this study used parameters that can represent the effect on percentage of desulfurization and percent recovery of residue oil. The parameters for selecting the best solvent are determined by the percentage of desulfurization (D) and the best percent recovery of residual oil $(R)$ can be represented by solvent effectiveness (E). Solvent effectiveness (E) is calculated using equation 1 .

$E=\frac{R}{100-D}$

The calculated value of solvent effectiveness $(E)$ for methanol, ethanol, and propanol is shown in Table 2. Based on Table 2, it could be concluded that ethanol has the highest effectiveness which is 9.0 compared to 
methanol 5.6 and propanol 5.0. Therefore, it could be concluded that in this study the best solvent for the extraction stage is ethanol.

The number of stage used in the extraction step was observed. By using ethanol as the best solvent, and $100 \mathrm{~mL}$ residue oil, residue oil/ $\mathrm{H}_{2} \mathrm{O}_{2}$ ratio $25(\mathrm{v} / \mathrm{v})$, residue oil/catalyst ratio $10(\mathrm{v} / \mathrm{v})$, oxidation temperature $50^{\circ} \mathrm{C}, 2 \mathrm{~h}$ oxidation time, extraction temperature $30^{\circ} \mathrm{C}$, $30 \mathrm{~min}$ extracting time and residue oil/solvent ratio of 1 $(\mathrm{v} / \mathrm{v})$, the effect of extraction stages was presented in Fig. 8. The modifications extraction step that repeated for several stages gives positive results. The percent desulfurization is increase within the number of stage, so that the modification give opportunity to obtain more environmental friendly residue oil.

\section{CONCLUSION}

From the data results and analysis of this study, the oxidative desulfurization with extraction step modifications could be applied to remove sulfur contaminant in residue oil. This process is applicable in industrial process. The sulfur content of the oil residue (condensate) has been reduced from total sulfur 386.26 to $35.94 \mathrm{ppm}$ (desulfurization $90.7 \%$ ) by oxidative desulfurization method with oxidation step operating condition were residue oil/ $/ \mathrm{H}_{2} \mathrm{O}_{2}$ ratio of $25(\mathrm{v} / \mathrm{v})$ and residue oil/acetic acid ratio of $30(\mathrm{v} / \mathrm{v})$ and oxidation temperature of $50{ }^{\circ} \mathrm{C}$. After oxidation step, it was then continued to extraction step with residue oil/ethanol ratio of $1(\mathrm{v} / \mathrm{v})$ repeated 4 stage with. The use of acetic acid catalysts was better than formic acid on sulfur removal in residue oil (condensate), where percent of desulfurization for acetic acid was $71.9 \%$ while formic acid only reaches $64.6 \%$. Ethanol showed the highest yield at the extraction stage compared to methanol and propanol, with the best percentage of desulfurization produced at $90.7 \%$ while methanol and propanol $86.6 \%$ and $83.3 \%$, respectively.

\section{ACKNOWLEDGEMENT}

This research was supported by Chemical Engineering Thermodynamic Laboratory, Institut Teknologi Sepuluh Nopember (ITS) and Penelitian Dana Mandiri ITS 2017.

\section{REFERENCES}

[1] Hayyan, M., Ibrahim, M.H., Hayyan, A., AINashef, I.M., Alakrach, A.M., Abdulkader, M., and Hashim, M.A., 2015, Facile route for fuel desulfurization using generated superoxide ion in ionic liquids, Ind. Eng. Chem. Res., 54 (49), 12263-12269.
[2] Saikia, B.K., Khound, K., and Baruah, B.P., 2014, Extractive de-sulfurization and de-ashing of high sulfur coals by oxidation with ionic liquids, Energy Convers. Manage., 81, 298-305.

[3] Boniek, D., Figueiredo, D., dos Santos, A.F.B., and Stoianoff, M.A.R., 2015, Biodesulfurization: A mini review about the immediate search for the future technology, Clean Technol. Environ. Policy, 17 (1), 29-37.

[4] Mei, H., Mei, B.W., and Yen, T.F., 2003, A new method for obtaining ultra-low sulfur diesel fuel via ultrasound assisted oxidative desulfurization, Fuel, 82 (4), 405-414.

[5] Zhao, H., and Baker, G.A., 2015, Oxidative desulfurization of fuels using ionic liquids: $A$ review, Front. Chem. Sci. Eng., 9 (3), 262-279.

[6] Srivastava, V.C., 2012, An evaluation of desulfurization technologies for sulfur removal from liquid fuels, RSC Adv., 2 (3), 759-783.

[7] Shang, H., Du, W., Liu, Z., and Zhang, H., 2013, Development of microwave induced hydrodesulfurization of petroleum streams: A review, J. Ind. Eng. Chem., 19 (4), 1061-1068.

[8] Saleh, T.A., 2016, Applying Nanotechnology to the Desulfurization Process in Petroleum Engineering, IGI Global, Hershey-PA, USA, 1-555.

[9] Alipoor, Z., Behrouzifar, A., Rowshanzamir, S., and Basmi, M., 2015, Electrooxidative desulfurization of a thiophene-containing model fuel using a square wave potentiomentry technique, Energy Fuels, 29 (5), 3292-3301.

[10] Capel-Sanchez, M.C., Perez-Presas, P., CamposMartin, J.M., and Fierro, J.L.G., 2010, Highly efficient deep desulfurization of fuels by chemical oxidation, Catal. Today, 157 (1-4), 390-396.

[11] Te, M., Fairbridge, C., and Ring, Z., 2001, Oxidation reactivities of dibenzothiophenes in polyoxometalate $/ \mathrm{H}_{2} \mathrm{O}_{2}$ and formic acid $/ \mathrm{H}_{2} \mathrm{O}_{2}$ systems, Appl. Catal., A, 219 (1-2), 267-280.

[12] Dehkordi, A.M., Kiaei, Z., and Sobati, M.A., 2009, Oxidative desulfurization of simulated light fuel oil and untreated kerosene, Fuel Process. Technol., 90 (3), 435-445.

[13] Sobati, M.A., Dehkordi, A.M., and Shahrokhi, M., 2010, Liquid-liquid extraction of oxidized sulfurcontaining compounds of non-hydrotreated kerosene, Fuel Process. Technol., 91 (11), 13861394.

[14] Xiao, C., Rehman, A., and Zeng, X., 2015, Evaluation of the dynamic electrochemical stability of ionic liquid-metal interfaces againts reactive oxygen species using an in situ electrochemical quartz crystal microbalance, RSC Adv., 5 (40), 31826-31836. 
[15] Rogers, R.D., and Seddon, K.R., 2003, Ionic liquids-Solvents of the future?, Science, 302 (5646), 792-793.

[16] Ibrahim, M.H., Hayyan, M., Hashim, M.A., Hayyan, A., and Hadj-Kali, M.K., 2016, Physycochemical properties of piperidinium, ammonium, pyrrolidinium and morpholinium cations based ionic liquids paired with bis(trifluoromethylsulfonyl)imide anion, Fluid Phase Equilib., 427, 18-26.

[17] Nuhu, A.A., 2013, Bio-catalytic desulfurization of fossil fuels: A mini review, Rev. Environ. Sci. Biotechnol., 12 (1), 9-23.

[18] Bachmann, R.T., Johnson, A.C., and Edyvean, G.J., 2014, Biotechnology in the petroleum industry: An overview, Int. Biodeterior. Biodegrad., 86, 225-237.
[19] Soleimani, M., Bassi, A., and Margaritis, A., 2007, Biodesulfurization of refractory organic sulfur compounds in fossil fuels, Biotechnol. Adv., 25 (6), 570-596.

[20] Yu, G., Lu, S., Chen, H., and Zhu, Z., 2005, Diesel fuel desulfurization with hydrogen peroxide promoted by formic acid and catalyzed by activated carbon, Carbon, 43 (11), 2285-2294.

[21] Rubio, M., Ramírez-Galicia, G., and López-Nava, L.J., 2005, Mechanism formation of peracids, J. Mol. Struct. THEOCHEM, 726 (1-3), 261-269. 